\title{
First records of ectoparasitic insects (Diptera: Hippoboscoidea) of bats in the department of Caldas, Colombia
}

\author{
Jorge Raigosa Álvarez ${ }^{14}$; Carolina García Osorio ${ }^{1,5}$; Analía Gladys Autino ${ }^{2,6}$ \& Lucimar Gomes Dias ${ }^{3}$ \\ 1 Universidad de Caldas (UCALDAS), Facultad de Ciencias Exactas y Naturales, Programa de Biología. Manizales, Colombia. \\ 2 Universidad Nacional de Tucumán (UNT), Facultad de Ciencias Naturales e Instituto Miguel Lillo, Programa de Investigaciones de Biodiversidad \\ Argentina (PIDBA). San Miguel de Tucumán, Tucumán, Argentina. \\ ORCID: http://orcid.org/0000-0003-2117-0378. E-mail: agautino@yahoo.com.ar (corresponding author) \\ 3 Universidad de Caldas (UCALDAS), Facultad de Ciencias Exactas y Naturales, Grupo de Investigación Bionat: Biodiversidad y Recursos \\ Naturales. Manizales, Caldas, Colombia. ORCID: http://orcid.org/0000-0001-6480-7688. E-mail: lucimar.dias@ucaldas.edu.co \\ ${ }^{4}$ ORCID: http://orcid.org/0000-0002-0853-8062. E-mail: biojorgee@gmail.com \\ ${ }^{5}$ ORCID: http://orcid.org/0000-0003-4950-6339. E-mail: biometalosorio@gmail.com \\ ${ }^{6}$ Programa de Conservación de los Murciélagos de Argentina (PCMA), Cátedra de Vertebrados. Tucumán, Argentina.
}

\begin{abstract}
In Colombia, the taxonomical understanding of ectoparasites (Diptera: Streblidae and Nycteribiidae) of bats is scarce, despite the high diversity of hosts. This fact reflects the lack of important information on the group and poses the need for studies that expand the knowledge on bat ectoparasites in different regions of the country. The aim of this study was to contribute pioneer knowledge on bat ectoparasitic insects in the department of Caldas, located in the Central Andes Mountain range of Colombia. We assessed 318 bats from four eco parks in the city of Manizales, and collected 234 ectoparasitic insects. We provide the first report of the family Streblidae for Caldas, with seven genera and eight species: Anastrebla caudiferae Wenzel, 1976, Anatrichobius scorzai Wenzel, 1966, Exastinion oculatum Wenzel, 1976, Megistopoda proxima (Séguy, 1926), Paratrichobius longicrus Ribeiro, 1907, Paraeuctenodes similis Wenzel, 1976, Trichobius longipes Rudow, 1871, and Trichobius tiptoni Wenzel, 1976. In addition, we report the species Basilia ferrisi Schuurmans Stekhoven, 1931 and Basilia sp. for the family Nycteribiidae.
\end{abstract}

Key-Words. Insects; Ectoparasites; Bats; Caldas.

\section{INTRODUCTION}

In the last two decades, the study of bat ectoparasites has shown important advances in South America (Autino \& Claps, 2000; Graciolli \& Carvalho, 2001; Presley, 2004; Graciolli et al., 2007; Dick et al., 2007; Autino et al., 2009, 2011, among others).

Currently, seven orders and approximately 6,000 species of mammal ectoparasitic insects have been registered. Of these, four orders (with approximately 687 species) have been reported as bat ectoparasites (Marshall, 1981).

The South American countries with the most studies on ectoparasitic insects include Argentina (Autino et al., 1999, 2009; Autino \& Claps, 2000), Brazil (Graciolli \& Carvalho, 2001; Santos et al., 2009; Graciolli et al., 2010; Almeida et al., 2011), Venezuela (Wenzel, 1976; Guerrero, 1994a, b, 1995a, b), Bolivia (Dick et al., 2007), Peru (Guerrero, 1996b; Claps et al., 2005; Graciolli et al.,
2007; Autino et al., 2011), and Paraguay (Presley, 2004; Dick \& Gettinger, 2005). In South America, the most representative bat ectoparasitic insects are Streblidae and Nycteribiidae (Wenzel, 1970; Guerrero, 1993, 1994a, b, 1995a, b, 1996a, 1997; Autino \& Claps, 2000; Dick \& Gettinger, 2005; Dick, 2006; Graciolli et al., 2007). Other insect groups that exclusively parasitize bats are Hemiptera (Polyctenidae and some species of Cimicidae) and Siphonaptera (Ischnopsyllidae), as well as Hectopsylla (Rhynchopsyllus) pulex (Haller, 1880) (Tungidae), Craneopsylla m. minerva (Rothschild, 1903) and C. m. wolffhuegeli (Rothschild, 1909) (Stephanocircidae) (Autino \& Claps, 2000; Lareschi et al., 2016).

In Colombia, three orders, five families, 21 genera, and 85 bat ectoparasitic insect species are known to date (Bequaert, 1940; Guerrero, 1997; Marinkelle \& Grose, 1981; Tarquino-Carbonell et al., 2015; Dick et al., 2016; Graciolli et al., 2016; Durán et al., 2017). The study by Bequaert (1940) 
was the first effort to study bat ectoparasitic insects from different localities of Colombia and Panamá. Later on, Marinkelle \& Grose (1981) published an extensive list on Colombian bat ectoparasites of the orders Diptera, Hemiptera, and Siphonaptera. Recently, TarquinoCarbonell et al. (2015) conducted a study on ectoparasites of chiropterofauna in the vereda Chorrillo, municipality of Ambalema, Tolima. Meanwhile, Durán et al. (2017) made the first report of Streblidae for the department of Sucre. Other contributions include the catalogues on Streblidae of the New World by Wenzel (1970) and Guerrero (1997), which include the species found in Colombia; in addition to the studies by Dick et al., 2016 and Graciolli et al., 2016 on Streblidae and Nycteribiidae species found in the country.

Despite the above, the information available for Colombia is scarce in comparison to other countries. Furthermore, there are no detailed studies on the taxonomy and/or composition of ectoparasitic species in several regions of the country. Considering the high diversity of bats in Colombia, this study aims to contribute to the understanding of ectoparasitic insects (Streblidae and Nycteribiidae) and their hosts, including the first reports for the department of Caldas, by studying bats and their ectoparasites in eco parks in the region.

\section{MATERIAL AND METHODS}

\section{Study area}

Sampling was done in four eco parks of the municipality of Manizales, department of Caldas (Fig. 1). Ecoparque Alcázares-Arenillo: located in the southwestern region of the municipality of Manizales $\left(05^{\circ} 04^{\prime} \mathrm{N}\right.$, $75^{\circ} 32^{\prime} \mathrm{W}$ ), it has an extension of $70.55 \mathrm{Ha}$, altitude ranging between 1,730 $\mathrm{m}$ a.s.l. and 1,960 $\mathrm{m}$ a.s.l., and an average annual precipitation of 2,223 $\mathrm{mm}$ (Arango et al., 2007). This area is inhabited by species such as: Fraxinus chin-

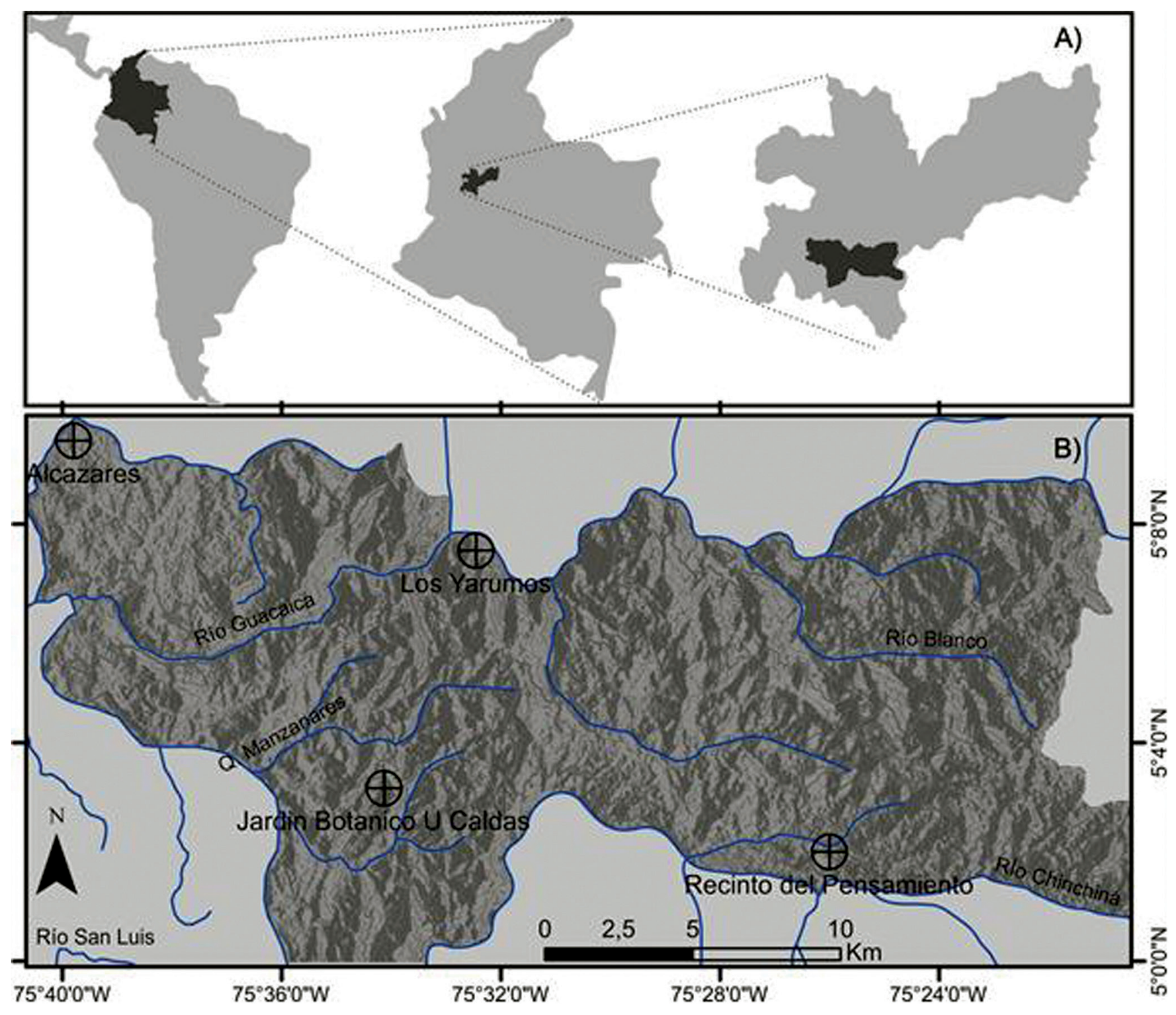

Figure 1. (A) Colombia, Caldas, Manizales. (B) Digital elevation model of Manizales, showing the eco parks network of the city: Alcazares-Arenillo, Los Yarumos, Jardín Botánico de la Universidad de Caldas, El Recinto del Pensamiento. 
ensis Roxb, 1820, Cecropia peltata Linneo, 1758, Salix sp., Dracaena draco (Linneo, 1767), Verbesina sp., Guadua angustifolia Kunth, 1822, Schefflera sp. (Forst \& Forst, 1775), Eucalyptus sp. (Héritier, 1789), Cyathea sp., and Toxicodendron sp., as well as species of Piperaceae and Moraceae. An area of particular interest in this eco park contains pastures and gardens with ornamental plants, such as Musa paradisiaca Linneo, 1753, Solanum lycopersicum Linneo, 1753, Coffea arabica Linneo, 1753, Allium cepa Linneo, 1753, and Phaseolus sp. (Arango et al., 2007). Jardín Botánico de la Universidad de Caldas: Located in southeast Manizales $\left(05^{\circ} 04^{\prime} \mathrm{N}, 75^{\circ} 31^{\prime} \mathrm{W}\right)$, it has an extension of $7 \mathrm{Ha}$, at 2,150 $\mathrm{m}$ a.s.l., with an average precipitation over $1,800 \mathrm{~mm}$ (Corpocaldas, 2002). It is forested predominantly with trees of the species Quercus humboldtii Bonpl., 1805, Podocarpus oleifolius D. Don, 1824, Eucalyptus sp., Dendropanax sp., and Cecropia sp. Other abundant plants include Monstera deliciosa Liebm, 1849 and Asplenium sp. Recinto del Pensamiento "Jaime Restrepo Mejía": A natural reserve in the Montane Region (IGAC, 1990), located in eastern Manizales in the industrial sector of Maltería $\left(05^{\circ} 02^{\prime} \mathrm{N}, 75^{\circ} 26^{\prime} \mathrm{W}\right)$, it extends $176 \mathrm{Ha}$, all at 2,250 m a.s.l. The vegetation is predominantly Podocarpus sp. and Alnus acuminata Kunth, 1817, Fraxinus chinensis, Guadua angustifolia, Piper sp. and species of Moraceae in primary reforestation. Ecoparque Los Yarumos: Located in northeastern Manizales $\left(05^{\circ} 03^{\prime} \mathrm{N}, 75^{\circ} 28^{\prime} \mathrm{W}\right)$, at $2,153 \mathrm{~m}$ a.s.l., with an extension of $70.9 \mathrm{Ha}$ (Arias, H. pers. comm. 2012). There are also $31.14 \mathrm{Ha}$ in the process of secondary regeneration, following active intervention. This area was previously used for livestock farming, and was later destined for reforestation (Corpocaldas, 2002), with the inclusion of several species of Cecropia sp., Alnus acuminata, and Smallanthus sp.

\section{Material collection and identification}

Sampling was conducted from May to November 2014. Six $12 \mathrm{~m} \times 2.5 \mathrm{~m}$ mist nets were utilized for bat capturing; the nets were relocated nightly to cover the greatest possible area. In total, 2,304 net hours were obtained from the four sampled zones. Morphometric data were collected from the bats according to Barquez (1987), along with additional data including sex, reproductive status, developmental stage, temperature, and weight. Bat identification was done according to the keys by Linares (1986), Timm et al., (1999); Muñoz (2001); Mantilla-Meluk \& Baker (2006); Gardner (2007); Zurc \& Velazco (2010); Solari et al. (2013). Several bats were taxidermized, including at least one individual per species (voucher), and eventually deposited in the Colección de Mamíferos del Museo de Historia Natural de la Universidad de Caldas (MHN-UC). Species collection was registered under permit number 215, emitted June $19^{\text {th }}$, 2014 by the Corporación Autónoma Regional de Caldas (CORPOCALDAS).

Ectoparasites were collected from each live bat by screening the fur using a fine point tweezer and then ob- served under a stereoscopic magnifying glass (Graciolli \& Carvalho, 2001). The specimens were deposited in Eppendorf tubes with $70 \%$ alcohol and later photographed in the laboratory using a Leica MC170 camera coupled to a Leica M205 stereomicroscope. The ectoparasites were identified using the taxonomic keys by Guimarães (1946), Guimarães \& D'Andretta (1956), Wenzel et al. (1966), Wenzel (1970, 1976), Guerrero (1995a, b), Autino et al. (1999), Graciolli \& Carvalho (2001), and Dick \& Miller (2010), among others, and the identifications were further confirmed by experts in the field.

Finally, the ectoparasites insects were deposited in the Colección Entomológica del Programa de Biología at the Universidad de Caldas (CEBUC) and the CMLA (Colección de Anexos de la Colección Mamíferos Lillo, de la Facultad de Ciencias Naturales e Instituto Miguel Lillo, Universidad Nacional de Tucumán, Argentina). Each Streblidae and Nycteribiidae specimen was catalogued by its corresponding number in the CMLA and deposited in the same collection.

\section{Data analysis}

Parasitism was assessed by prevalence values $(P)$, which indicate the proportion or number of infested host bats in a population compared to the total number of bats examined. Furthermore, we calculated the intensity of infestation (I), also called parasitic load, which is defined as the number of parasites that live in or on a host (Wisnivesky, 2003). Finally, we estimated the specificity index (SE), which corresponds to the percentage of parasitism specificity of each ectoparasitic species in relation to each host bat species (Dick \& Gettinger, 2005): Specificity index $(\mathrm{SI})=(($ Abundance of $\mathrm{X}$ ectoparasitic species in each host species/Total abundance of the ectoparasitic species) (100)).

\section{RESULTS}

We collected a total of 234 ectoparasitic insects of the order Diptera (Hippoboscoidea), distributed in 10 species, eight genera, and two families (Table 1): Streblidae (91.2\%) with eight species and Nycteribiidae (8.8\%) with two. The most abundant species in the eco parks were P. longicrus (Fig. 2) (38.39\%), P. similis (Fig. 3) (22.22\%), T. tiptoni (Fig. 4) (8.12\%), and A. caudiferae (Fig. 5) (8.12\%) (all of these belong to Streblidae), while the remaining species showed relative abundances below $8.12 \%$ (Table 1). We identified the species B. ferrisi (2.56\%), belonging to Nycteribiidae. We also collected male specimens of the genus Basilia Miranda-Ribeiro, 1903, but these could not be identified to the species level, since most available identification keys and the descriptions correspond to females.

Three hundred eighteen host bat specimens were captured (Table 2), of which 129 exhibited ectoparasites. We identified 20 bat species distributed in 13 genera and three families: Phyllostomidae (90.8\%), Vespertilionidae 
(8.8\%), and Molossidae (0.4\%). The dominant species were: Artibeus lituratus (Olfers, 1818) (38.4\%), Carollia brevicauda (Schinz, 1821) (27\%), Dermanura bogotensis (Andersen, 1906) (9.7\%), and Glossophaga soricina (Pallas, 1776) (4.7\%) (all belonging to Phyllostomidae). Of the total bats captured, six species were not parasitized: Platyrrhinus dorsalis (Thomas, 1900) (Phyllostomidae), Eptesicus brasiliensis (Desmarest, 1819), Eptesicus chiriqui-

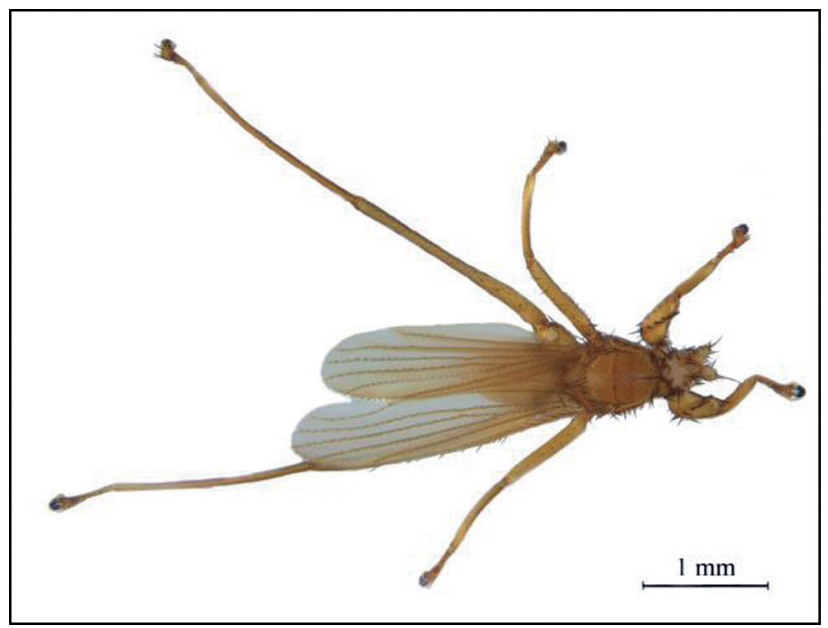

nus Thomas, 1920, Eptesicus fuscus (Beauvois, 1796), Myotis riparius Handley, 1960 (Vespertilionidae), and Molossus molossus (Pallas, 1776) (Molossidae).

The family Phyllostomidae was the most parasitized, specifically, by eight species of Streblidae; while the family Vespertilionidae was parasitized by three species, one belonging to Streblidae ( $A$. scorzai) and two to Nycteribiidae (B. ferrisi and Basilia sp.). We found that $82 \%$

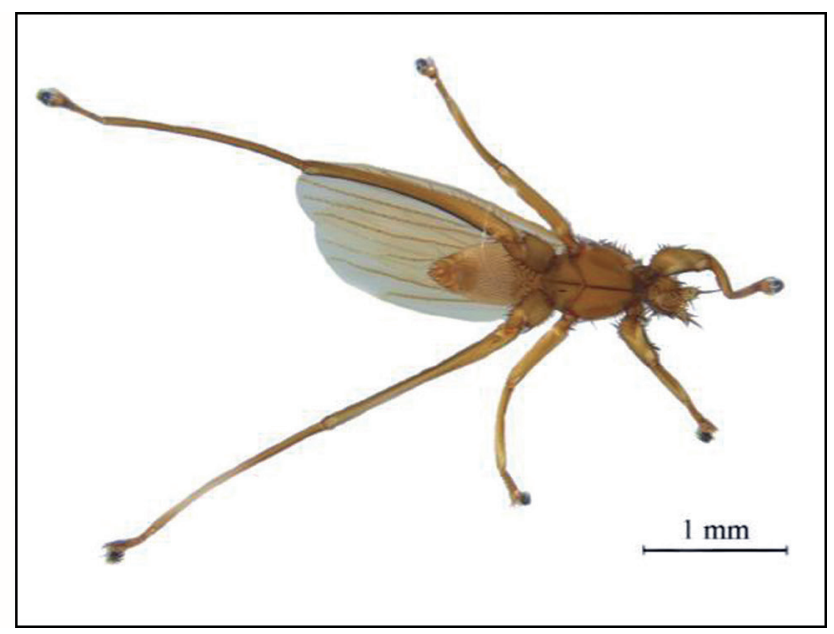

Figure 2. Dorsal and ventral macroscopic view of Paratrichobius longicrus (Diptera, Streblidae) (CEBUC Dip. Streblidae C-Dip0140) on Artibeus lituratus.
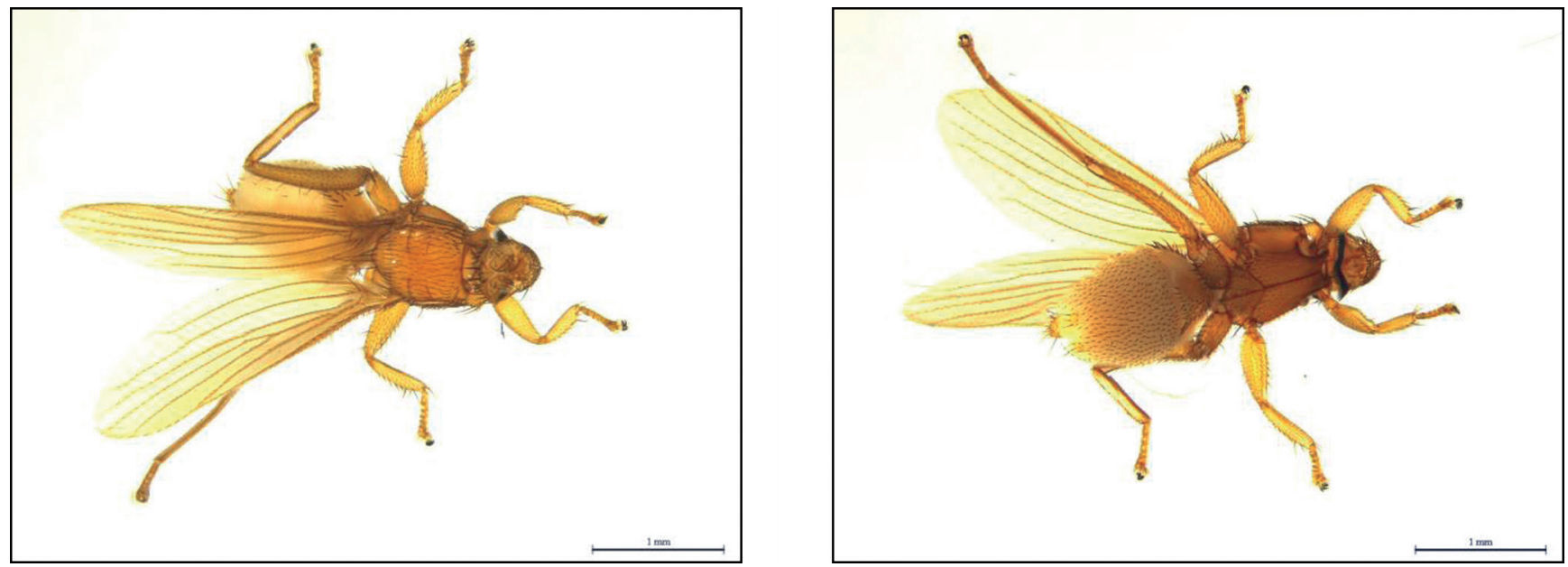

Figure 3. Dorsal and ventral macroscopic view of Paraeuctenodes similis (Diptera, Streblidae) (CEBUC Dip. Streblidae C-Dip0145) on Carollia brevicauda.
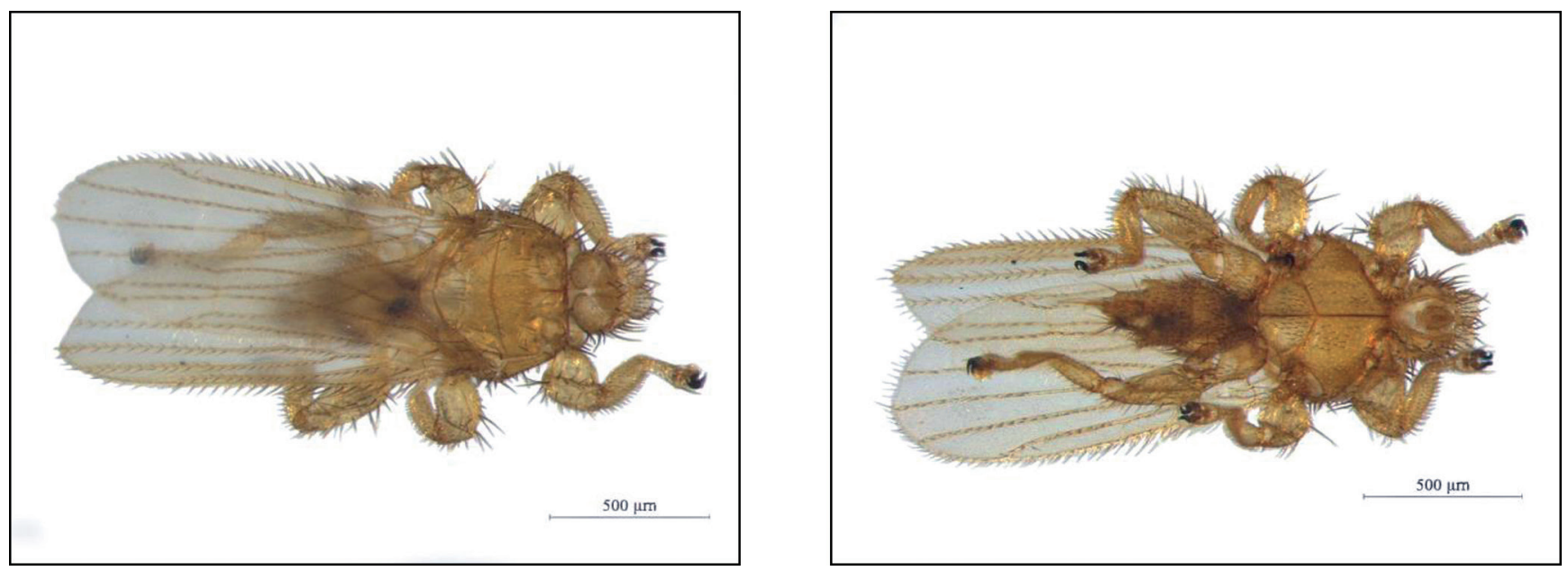

Figure 4. Dorsal and ventral macroscopic view of Trichobius tiptoni (Diptera, Streblidae) (CEBUC Dip. Streblidae C-Dip0142) on Carollia brevicauda. 
Table 1. Ectoparasitic insects species of Streblidae and Nycteribiidae (Diptera) and their host bats, with relative abundance (RA) and specificity in$\operatorname{dex}(\mathrm{SI})$. The specificity behavior to the host is also shown (HS): M: monoxene (found on only one host species); 0: oligoxene (found on different bat hosts species, but of the same genus); PI: pleioxene (found on different species and genera of host bats, but of the same family); Po: polyxene (found on different species and genera of host bats, and different families).

\begin{tabular}{|c|c|c|c|c|c|c|}
\hline Diptera (n) & & RA (\%) & Chiroptera (n) & & SI & HS \\
\hline \multicolumn{7}{|l|}{ Streblidae } \\
\hline \multirow[t]{4}{*}{ Anastrebla caudiferae } & (1) & 8.12 & Anoura caudifer & (1) & 5.26 & $\mathrm{PI}$ \\
\hline & (9) & & Carollia brevicauda & (2) & 47.37 & \\
\hline & (1) & & Enchisthenes hartii & (1) & 5.26 & \\
\hline & (8) & & Glossophaga soricina & $(2)$ & 42.11 & \\
\hline \multirow[t]{2}{*}{ Anatrichobius scorzai } & (1) & 0.85 & Myotis oxyotus & (1) & 50.00 & 0 \\
\hline & (1) & & Myotis nigricans & (1) & 50.00 & \\
\hline \multirow[t]{2}{*}{ Exastinion oculatum } & (12) & 6.84 & Carollia brevicauda & (3) & 75.00 & $\mathrm{Pl}$ \\
\hline & (4) & & Glossophaga soricina & (1) & 25.00 & \\
\hline Megistopoda proxima & (5) & 2.14 & Sturnira ludovici & (3) & 100.0 & M \\
\hline \multirow[t]{3}{*}{ Paraeuctenodes similis } & (49) & 22.22 & Carollia brevicauda & (30) & 94.23 & $\mathrm{Pl}$ \\
\hline & (1) & & Dermanura bogotensis & (1) & 1.92 & \\
\hline & (2) & & Glossophaga soricina & (2) & 3.85 & \\
\hline \multirow[t]{6}{*}{ Paratrichobius longicrus } & (65) & 38.89 & Artibeus lituratus & (33) & 71.43 & $\mathrm{PI}$ \\
\hline & $(2)$ & & Carollia brevicauda & $(2)$ & 2.20 & \\
\hline & (9) & & Dermanura bogotensis & (7) & 9.89 & \\
\hline & (5) & & Enchisthenes hartii & (3) & 5.49 & \\
\hline & (7) & & Platyrrhinus helleri & (2) & 7.69 & \\
\hline & (3) & & Platyrrhinus vittatus & (3) & 3.30 & \\
\hline \multirow[t]{3}{*}{ Trichobius longipes } & (6) & 3.85 & Artibeus lituratus & (6) & 66.67 & $\mathrm{Pl}$ \\
\hline & (2) & & Carollia brevicauda & (1) & 22.22 & \\
\hline & (1) & & Sturnira ludovici & (1) & 11.11 & \\
\hline \multirow[t]{4}{*}{ Trichobius tiptoni } & (1) & 8.12 & Artibeus lituratus & (1) & 5.26 & $\mathrm{Pl}$ \\
\hline & (13) & & Carollia brevicauda & (9) & 68.42 & \\
\hline & (2) & & Dermanura bogotensis & (1) & 10.53 & \\
\hline & (3) & & Glossophaga soricina & (2) & 15.79 & \\
\hline \multicolumn{7}{|l|}{ Nycteribiidae } \\
\hline \multirow[t]{4}{*}{ Basilia ferrisi } & (1) & 2.56 & Carollia brevicauda & (1) & 6.67 & $P_{0}$ \\
\hline & (9) & & Histiotus montanus & (3) & 60.00 & \\
\hline & (2) & & Myotis nigricans & (1) & 13.33 & \\
\hline & (3) & 6.41 & Myotis keaysi & (2) & 20.00 & \\
\hline \multirow[t]{3}{*}{ Basilia sp. } & (2) & & Glossophaga soricina & (1) & 33.33 & $P_{0}$ \\
\hline & (2) & & Myotis keaysi & (1) & 33.33 & \\
\hline & (2) & & Myotis oxyotus & (1) & 33.33 & \\
\hline
\end{tabular}

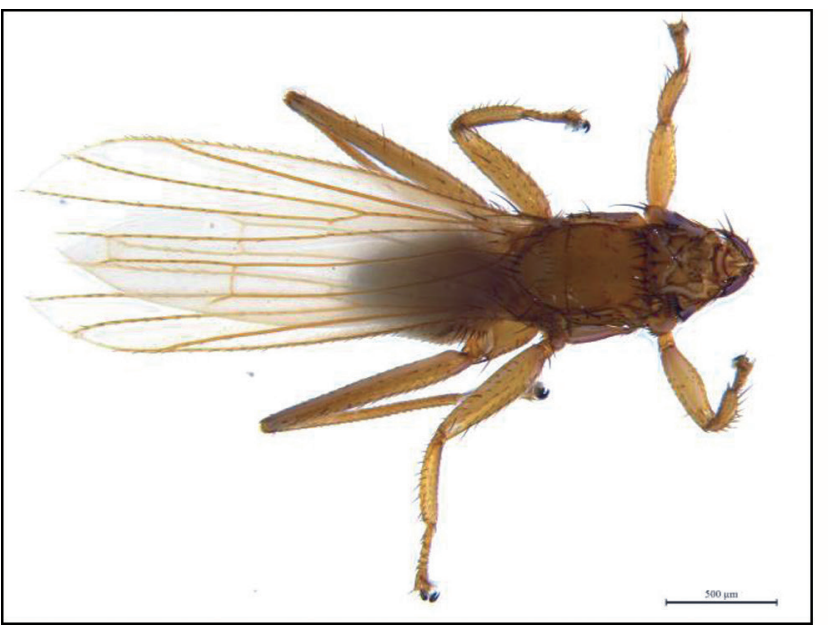

Table 2. Bat host species and number of captured specimens with their relative abundance (RA).

\begin{tabular}{|c|c|c|}
\hline Bat species & Total & RA\% \\
\hline \multicolumn{3}{|l|}{ Phyllostomidae } \\
\hline \multicolumn{3}{|l|}{ Stenodermatinae } \\
\hline Artibeus lituratus & 122 & 38.4 \\
\hline Dermanura bogotensis & 31 & 9.7 \\
\hline Enchisthenes hartii & 10 & 3.1 \\
\hline Platyrrhinus helleri & 5 & 1.3 \\
\hline Platyrrhinus vittatus & 5 & 1.9 \\
\hline Platyrrhinus dorsalis & 1 & 0.3 \\
\hline Sturnira ludovici & 10 & 3.1 \\
\hline Vampyressa thyone & 1 & 0.3 \\
\hline \multicolumn{3}{|l|}{ Carollinae } \\
\hline Carollia brevicauda & 86 & 27 \\
\hline \multicolumn{3}{|l|}{ Glossophaginae } \\
\hline Anoura caudifer & 3 & 0.9 \\
\hline Glossophaga soricina & 15 & 4.7 \\
\hline \multicolumn{3}{|l|}{ Vespertilionidae } \\
\hline \multicolumn{3}{|l|}{ Myotinae } \\
\hline Eptesicus fuscus & 4 & 1.3 \\
\hline Eptesicus chiriquinus & 2 & 0.6 \\
\hline Eptesicus brasiliensis & 1 & 0.3 \\
\hline Histiotus montanus & 8 & 2.5 \\
\hline Myotis nigricans & 3 & 0.9 \\
\hline Myotis keaysi & 5 & 1.6 \\
\hline Myotis oxyotus & 3 & 0.9 \\
\hline Myotis riparius & 2 & 0.6 \\
\hline \multicolumn{3}{|l|}{ Molossidae } \\
\hline \multicolumn{3}{|l|}{ Molossinae } \\
\hline Molossus molossus & 1 & 0.3 \\
\hline Total & 318 & 1 \\
\hline
\end{tabular}

of specimens were collected from Phyllostomidae, while the remaining $12 \%$ were extracted from Vespertilionidae.

The hosts with the highest number of ectoparasites were: C. brevicauda (n 79), A. lituratus (n 67), G. soricina (n 17), and D. bogotensis (n 12). We captured eight host species that were parasitized by more than one ectoparasitic species: C. brevicauda (6 species of Streblidae and 1 sp. of Nycteribiidae); G. soricina (4 spp. of Streblidae, and 1 sp. of Nycteribiidae); A. lituratus and D. bogoten-

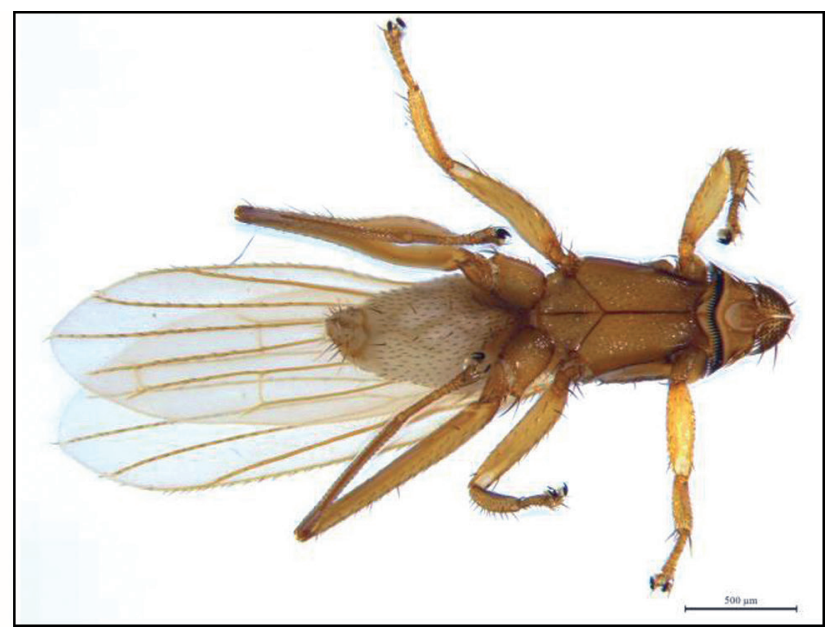

Figure 5. Dorsal and ventral macroscopic view of Anastrebla caudiferae (Diptera, Streblidae) (CEBUC Dip. Streblidae C-Dip0138) ectoparasite of Anoura caudifer. 
Table 3. Bat species with their corresponding Streblidae and Nycteribiidae ectoparasitic species and number $(\mathrm{N})$ of ectoparasites per host.

\begin{tabular}{|c|c|c|c|c|}
\hline Bat species & Streblidae & $\mathbf{N}$ & Nycteribiidae & N \\
\hline \multicolumn{5}{|l|}{ Phyllostomidae } \\
\hline \multicolumn{5}{|l|}{ Stenodermatinae } \\
\hline \multirow[t]{3}{*}{ Artibeus lituratus } & P. longicrus & 65 & & \\
\hline & T. longipes & 1 & & \\
\hline & T. tiptoni & 1 & & \\
\hline \multirow[t]{3}{*}{ Dermanura bogotensis } & P. longicrus & 9 & & \\
\hline & T. tiptoni & 2 & & \\
\hline & P. similis & 1 & & \\
\hline \multirow[t]{2}{*}{ Enchisthenes hartii } & A. caudiferae & 1 & & \\
\hline & P. longicrus & 5 & & \\
\hline Platyrrhinus helleri & P. longicrus & 7 & & \\
\hline Platyrrhinus vittatus & P. longicrus & 3 & & \\
\hline Platyrrhinus dorsalis & Not parasitized & 0 & & \\
\hline \multirow[t]{2}{*}{ Sturnira ludovici } & M.proxima & 5 & & \\
\hline & T. longipes & 1 & & \\
\hline Vampyressa thyone & Not parasitized & 0 & & \\
\hline \multicolumn{5}{|l|}{ Carollinae } \\
\hline \multirow[t]{6}{*}{ Carollia brevicauda } & A. caudiferae & 9 & B. ferrisi & 1 \\
\hline & E. oculatum & 12 & & \\
\hline & P. similis & 49 & & \\
\hline & P. longicrus & 2 & & \\
\hline & T. longipes & 2 & & \\
\hline & T. tiptoni & 13 & & \\
\hline \multicolumn{5}{|l|}{ Glossophaginae } \\
\hline Anoura caudifer & A. caudiferae & 1 & & \\
\hline \multirow[t]{4}{*}{ Glossophaga soricina } & A. caudiferae & 8 & Basilia sp. & 2 \\
\hline & E. oculatum & 4 & & \\
\hline & P. similis & 2 & & \\
\hline & T. tiptoni & 3 & & \\
\hline \multicolumn{5}{|l|}{ Vespertilionidae } \\
\hline \multicolumn{5}{|l|}{ Myotinae } \\
\hline Eptesicus fuscus & Not parasitized & 0 & & \\
\hline Eptesicus chiriquinus & Not parasitized & 0 & & \\
\hline Eptesicus brasiliensis & Not parasitized & 0 & & \\
\hline Histiotus montanus & & & B. ferrisi & 9 \\
\hline Myotis nigricans & A. scorzai & 1 & B. ferrisi & 2 \\
\hline \multirow{2}{*}{ Myotis keaysi } & & & B. ferrisi & 3 \\
\hline & & & Basilia sp. & 2 \\
\hline Myotis oxyotus & A. scorzai & 1 & Basilia sp. & 1 \\
\hline Myotis riparius & Not parasitized & 0 & & \\
\hline \multicolumn{5}{|l|}{ Molossidae } \\
\hline \multicolumn{5}{|l|}{ Molossinae } \\
\hline Molossus molossus & Not parasitized & 0 & & \\
\hline
\end{tabular}

sis (3 spp. of Streblidae); Enchisthenes hartii Thomas, 1892 and Sturnira ludovici (2 spp. of Streblidae); Myotis nigricans Schinz, 1821 (1 sp. of Streblidae and $1 \mathrm{sp}$. of Nycteribiidae); Myotis keaysi J.A. Allen, 1914 (2 spp. of Nycteribiidae). The remaining hosts showed parasitism by only one species of Nycteribiidae or Streblidae, or were not parasitized (Table 3).

Bat parasitism prevalences and intensities in the four ecological parks show the highest prevalence for Los Alcázares eco park and highest intensity for El Recinto del Pensamiento (Table 4).

Among the infested bat species, we found that Myotis oxyotus Peters, 1867, and M. nigricans showed the highest prevalence with $66.66 \%$, followed by C. brevicauda $51.16 \%$, E. hartii and G. soricina 40\%. Meanwhile, P. helleri showed the highest intensity with $87.5 \%$ (Table 5).
Table 4. Percentages of bat parasitism intensities and prevalences in each ecological park in Manizales: Jardín botánico Universidad de Caldas (JB), Ecoparque los Yarumos, (EY), Ecoparque los Alcázares (EA) and Ecoparque Recinto del Pensamiento (RP).

\begin{tabular}{ccc}
\hline Eco park & \% Prevalence & \% Intensity \\
\hline JB & 27.7 & 2.0 \\
EY & 37.9 & 2.1 \\
EA & 40.6 & 2.0 \\
RP & 35.7 & 6.5 \\
\hline
\end{tabular}

Table 5. Percentages of ectoparasitic insect intensities and prevalences for each bat species in the ecological parks in Manizales.

\begin{tabular}{lcc}
\hline \multicolumn{1}{c}{ Hosts (n infested $-\mathbf{n}$ total) } & \% Prevalence & Intensity \\
\hline Anoura caudiferae (1-3) & 33.3 & 0.333 \\
Artibeus lituratus (36-122) & 29 & 0.016 \\
Carollia brevicauda $(44-86)$ & 50 & 0.023 \\
Dermanura bogotensis (8-31) & 25.8 & 0.048 \\
Enchisthenes hartii (4- 10) & 40 & 0.15 \\
Glossophaga soricina (6-15) & 40 & 0.21 \\
Histiotus montanus (3-8) & 37.5 & 0.37 \\
Myotis keaysi (2-5) & 40 & 0.50 \\
Myotis nigricans (2-3) & 66.6 & 0.50 \\
Myotis oxyotus (2-3) & 66.6 & 0.50 \\
Myotis riparius (2-3) & 66.6 & 0.50 \\
Platyrrhinus helleri (2-4) & 50 & 0.85 \\
Platyrrhinus vittatus (3-6) & 50 & 0.16 \\
Sturnira sp. (3-10) & 30 & 0.20 \\
\hline
\end{tabular}

\section{DISCUSSION}

This study of ectoparasitic insects in bats of Caldas (Colombia) allows us to expand the understanding of the relations between ectoparasitic insects and their hosts. We found that the distribution and specificity of the ectoparasite is associated with the presence or absence of a given host species, and that the intensity and prevalence of insect parasitism in bats can vary according to the host species. For Colombia, there are reports of 19 genera and 73 species of Streblidae parasitizing Emballonuridae, Furipteridae, Molossidae, Mormoopidae, Natalidae, Noctilionidae, Phyllostomidae, and Vespertilionidae (Dick et al., 2016); and two genera and eight species of Nycteribiidae for Vespertilionidae, Phyllostomidae, and Thyropteridae (Graciolli et al., 2016). The 10 ectoparasitic species found in this study comprise $14 \%$ of the total species reported for the country and they represent the first records of Streblidae and Nycteribiidae (Diptera) for the department of Caldas.

Regarding Streblidae ectoparasites, $A$. caudiferae has been reported in Argentina, Bolivia, Brazil, Venezuela, and Colombia (Caldas in this study, Cauca, Cundinamarca, Huila, Nariño) (Bequaert, 1940; Wenzel, 1970; Guerrero, 1997; Graciolli \& Carvalho, 2001; Autino et al., 2009; Bertola et al., 2005; Dick et al., 2016). This species is associated with Phyllostomidae hosts in its area of distribution, including Anoura caudifer E. Geoffroy Saint-Hilaire, 1818 , as its primary host, and additionally Anoura geof- 
froyi Gray, 1838, A. lituratus, and G. soricina (Bertola et al., 2005). Here we also report C. brevicauda and E. hartii as accidental hosts. The species shows a pleioxene behavior throughout all its distribution area in Caldas.

Anatrichobius scorzai has been reported in Argentina, Bolivia, Brazil, Colombia (Caldas in this study, Huila), Costa Rica, Ecuador, Honduras, Panama, Peru, and Venezuela (Marinkelle \& Grose, 1981; Guerrero, 1997; Autino \& Claps, 2000; Graciolli, 2003; Autino et al., 2009; Dick et al., 2016). Hosts for this species mainly belong to the genus Myotis (Myotis albescens E. Geoffroy Saint-Hilaire, 1806, M. keaysi, M. nigricans, Myotis oxyotus) (Guerrero, 1997; Autino et al., 2009), although it has also been found on Lonchophylla robusta Miller, 1912 (Phyllostomidae), which might correspond to an accidental infestation, considering its preference for Vespertilionidae hosts.

Exastinion oculatum has a more restricted distribution, which includes Colombia (Caldas in this study, Huila) and Panama (Wenzel, 1976; Guerrero, 1997; Dick et al., 2016). This species prefers hosts of the genus Anoura, specifically Anoura cultrata Handley, 1960 and A. geoffroyi (Guerrero, 1997; Dick et al., 2016). In this study, we report the species parasitizing $C$. brevicauda and $G$. soricina, potentially accidental hosts, a finding that broadens the range of known hosts for the species. It displays a pleioxene behavior in Caldas, since it expands hosts. In the rest of its distribution, however, it exhibits an oligoxene behavior.

Megistopoda proxima has a wide distribution that spans several countries, from Mexico in the north to Argentina in the south of the continent. In Colombia, it has been reported in the departments of Huila, Nariño, Putumayo, Santander, Sucre, Tolima, and Valle del Cauca (Tarquino-Carbonell, et al., 2015; Dick et al., 2016; Durán et al., 2017) and is herein reported in Caldas. It has various hosts, mainly Phyllostomidae (Marinkelle \& Grose, 1981; Guerrero, 1997; Autino et al., 1999, 2009, 2011; Graciolli \& Carvalho, 2001; Tarquino-Carbonell et al., 2015; Dick et al., 2016; Durán et al., 2017), although it was also found on Noctilio leporinus Linnaeus, 1758 (Noctilonidae). This species behavior is polyxene in its distribution area, yet in Caldas, it was only found on S. Iudovici.

Paraeuctenodes similis has been reported in Bolivia, Brazil, Colombia (Caldas in this study, Huila, and Santander), Costa Rica, Ecuador, Peru, and Venezuela (Wenzel, 1976; Guerrero, 1996b, 1997; Graciolli \&Carvalho, 2001; Dick et al., 2016). Its hosts include C. brevicauda, C. perspicillata, Trachops cirrhosus Spix, 1823, Sturnira lilium E. Geoffroy, 1810 (Guerrero, 1996a; Graciolli \& Carvalho, 2001; Bertola et al., 2005). In this study, we extend the range of hosts to include $D$. bogotensis and $G$. soricina, which would be accidental hosts. The species has the same pleioxene behavior throughout its entire distribution.

Paratrichobius longicrus is a complex of species that parasitizes bats of the genera Artibeus and Platyrrhinus Saussure, 1860 (Wenzel et al., 1966). It is widely distributed in several countries, from Mexico in the north to Argentina in the south of the continent. In Colombia, it has been found in the departments of Antioquia,
Meta, Tolima, Valle del Cauca, and Caldas in this study. The species has a wide range of hosts, mainly of the family Phyllostomidae, although Molossops planirostris Peters, 1865 and Molossops temminckii Burmeister, 1854 (Molossidae) have also been reported (Graciolli \& Carvalho, 2001). Here, we report C. brevicauda, D. bogotensis, and Platyrrhinus helleri Peters, 1866 as hosts of $P$. longicrus. This species displays a polyxene behavior in its area of distribution, although, in Caldas, it is pleioxene.

Trichobius longipes is also a widely distributed species, from Guatemala in the north to Bolivia in the south. In Colombia, it has been reported in the departments of Antioquia, Huila, Magdalena, Meta, Norte de Santander, Sucre, Tolima, Valle del Cauca (Guerrero, 1997; Graciolli \& Carvalho, 2001; Tarquino-Carbonell et al., 2015; Dick et al., 2016; Durán et al., 2017), and Caldas in this study. It has several hosts of the family Phyllostomidae, in addition to Rhynchonycteris nasso Wied-Neuwied, 1820 (Emballonuridae), N. leporinus (Noctilionidae), Molossus ater (Molossidae) (Graciolli \& Carvalho, 2001). In this study, we include A. lituratus, C. brevicauda, and S. Iudovi$\mathrm{Ci}$ as further hosts. This species is clearly polyxene in its distribution area, however, in Caldas its behavior is pleioxene.

Trichobius tiptoni is distributed in Bolivia, Brazil, Colombia (Nariño and Caldas in this study), French Guiana, and Venezuela (Guerrero, 1997; Graciolli \& Carvalho, 2001; Dick et al., 2007, 2016). Its hosts include A. caudifer, Chrotopterus auritus Peters, 1856, C. perspicillata, P. helleri, S. lilium, and S. Iudovici. Herein, we also report A. lituratus, C. brevicauda, D. bogotensis, and G. soricina. This species' behavior in Caldas is pleioxene, a finding that matches the rest of its distribution area and it is always found on hosts of the family Phyllostomidae.

For the Nycteribiidae family, we report ectoparasites of the species $B$. ferrisi. The species was reported in Brazil, Colombia (Antioquia, Bolívar, Caldas in this study, Chocó, Meta, Santander), Costa Rica, Guatemala, Guiana, Panama, Peru, and Venezuela (Graciolli et al., 2007, 2016). Its range of hosts includes Desmodus rotundus E. Geoffroy, 1810, L. robusta, Uroderma bilobatum Peters, 1866 (Phyllostomidae), Dasypterus sp., Myotis albescens, $M$. keaysi, M. nigricans, $M$. oxyotus, $M$. riparius, M. simus Thomas, 1901 (Vespertilionidae), M. molossus (Molossidae) (Guerrero, 1997; Graciolli et al., 2007). Furthermore, in this study, we include Histiotus montanus Philippi \& Landbeck, 1861. The species clearly exhibits a polyxene behavior in its distribution area; although, in Caldas, it is oligoxene.

Our findings showed that, in Caldas, each species behavior varies in terms of its hosts, which is likely due to a smaller sample area compared to the extensive distribution of each ectoparasite. As for the hosts, the family Phyllostomidae showed the highest species richness and abundance (11 spp.), encompassing 24\% of the reported species for Caldas (48 spp.) (Castaño, 2012). This is followed by Vespertilionidae with eight species (61\%) out of 13 species reported for Caldas and Molossidae with one species (20\%) out of five reported for the department (Castaño, 2012). The forests in Caldas have un- 
dergone transformations from anthropic intervention and expansion of the agricultural frontier, among other causes, that affect the biodiversity of host bats and mammals in general (Castaño, 2012). This study on Streblidae and Nycteribiidae ectoparasites and their hosts in Caldas (Manizales) contributes a basis for future studies in other departments of Colombia that have not yet been sampled. Our study documents the enrichment of the diversity of host and ectoparasitic fauna in the country, in an ever-changing landscape.

\section{ACKNOWLEDGEMENTS}

To the Vicerrectoría de Investigaciones y Posgrados of the Universidad de Caldas for funding the project titled "Contribution to the knowledge of fauna associated with the ecoparks of Manizales" (Contribución al conocimiento de la fauna asociada a los ecoparques de Manizales) (Code: 0869113). To the Laboratorio de Colecciones Biológicas, Colección Entomológica del Programa de Biología de la Universidad de Caldas - CEBUC and Centro de Museos of the Universidad de Caldas for the infrastructure provided. We thank Jennifer Richardson for the grammatical revision of the English.

\section{REFERENCES}

Almeida, J.C.; Silva, S.P.; Serra, F.N.M. \& Valim, M.P. 2011. Ectoparasites (Insecta and Acari) associated with bats in Southeastern Brazil. Journal of Medical Entomology, 48: 753-757.

Arango, L.; Montes, J.M.; López, D.A. \& López, J.0. 2007. Mariposas (Lepidoptera: Papilionoidea, Hesperoidea), escarabajos coprófagos (Coleoptera: Scarabaeinae) y hormigas (Hymenoptera: Formicidae) del Ecoparque Alcázares Arenillo (Manizales, Caldas-Colombia). Boletín Científico Centro de Museos, Museo de Historia Natural, 11:390-409.

Autino, A.G. \& Claps, G.L. 2000. Catálogo de los insectos ectoparásitos de los murciélagos de Argentina. Insecta Mundi, 14: 192-209.

Autino, A.G.; Claps, G.L. \& Barquez, R.M. 1999. Insectos ectoparásitos de murciélagos de las yungas de la Argentina. Acta Zoologica Mexicana, 78: 119-169.

Autino, A.G.; Claps, G.L.; Barquez, R.B. \& Diaz, M.M. 2011. Ectoparasitic insects (Diptera: Streblidae and Siphonaptera: Ischnopsyllidae) of bats from Iquitos and surrounding areas (Loreto, Peru). Memorias do Instituto Oswaldo Cruz, 106(8): 917-925.

Autino, A.G.; Claps, G.L.; Sanchez, M.S. \& Barquez, R.B. 2009. New records of Bat Ectoparasites (Diptera, Hemiptera and Siphonaptera) from Northern Argentina. Neotropical Entomology, 38(2): 165-177.

Barquez, R.M. 1987. Los murciélagos de Argentina. (Tesis Doctoral no publicada). San Miguel de Tucumán, Facultad de Ciencias Naturales e IML, Universidad Nacional de Tucumán.

Bequaert, J. 1940. Moscas parasitas pupiparas de Colombia y Panamá. Revista de la Academia Colombiana Ciencias Exactas Físicas y Naturales, 3(12): 414-418.

Bertola, P.B.; Aires, C.C.; Favorito, S.E.; Graciolli, G.; Amaku, M. \& Rocha, M.P. 2005. Bat flies (Diptera: Streblidae, Nycteribiidae) parasitic on bats (Mammalia: Chiroptera) at Parque Estadual da Cantareira, São Paulo, Brazil: parasitism rates and host-parasite associations. Memorias do Instituto Oswaldo Cruz, 100(1): 25-32.
Castaño, H.J. 2012. Mamíferos de Caldas: un análisis de vacíos de información. Boletín Científico del Museo de Historia Natural, 16(2): 101-119.

Claps, G.L.; Autino, A.G. \& Barquez, R.M. 2005. Streblidae de murciélagos de Lima: dos citas nuevas para Perú. Revista de la Sociedad Entomológica Argentina, 64(1-2): 95-98.

Corpocaldas. 2002. Agenda para Gestión Ambiental del Municipio de Manizales. Corporación Autónoma Regional de Caldas. 232p.

Dick, C.W. 2006. The Streblid bat flies (Diptera; Streblidae) of Guatemala. In: Cano, E.B. (Ed.). Biodiversidad de Guatemala, Guatemala, Universidad del Valle de Guatemala. v. 1, p. 441-452.

Dick, C.W. \& Gettinger, D. 2005. A faunal survey of streblid flies (Diptera: Streblidae) associated with bats in Paraguay. Journal of Parasitology, 91(5): 1015-1024.

Dick, C.W. \& Miller, J.A. 2010. Streblidae. In: Brown, B.V.; Borkent, A.; Cumming, J.M.; Wood, D.M.; Woodley, N.E. \& Zumbado, M. (Eds.). Manual of Central American Diptera. Ottawa, National Research Council Press. p. $1249-1260$.

Dick, C.W.; Gettinger, D. \& Gardner, S. 2007. Bolivian Ectoparasites: A Survey of Bats (Mammalia Chiroptera). Comparative Parasitology, 74(2): 372-377.

Dick, C.W.; Graciolli, G. \& Guerrero, R. 2016. Family Streblidae. Zootaxa, 4122(1): 784-802.

Durán, A.A.; Álvarez García, D.M. \& Graciolli, G. 2017. Ectoparasitic flies (Diptera, Streblidae) on bats (Mammalia, Chiroptera) in a dry tropical forest in the northern Colombia. Papéis Avulsos de Zoologia, 57(8): 105-111.

Gardner, A.L. 2007. Mammals of South America. Volume 1, Marsupials, xenarthrans, shrews, and bats. Chicago, The University of Chicago Press.

Graciolli, G. 2003. Nova especie de Anatrichobius Wenzel, 1966 (Diptera Streblidae) do Brasil meridional. Revista Brasileira de Entomologia, 47: 55-58.

Graciolli, G. \& Carvalho, C.J.B. 2001. Moscas ectoparasitas (Diptera, Hippoboscoidea) de morcegos (Mammalia, Chiroptera) do Estado do Parana. II. Streblidae Chave pictórica para generos e especies. Revista Brasileira de Zoologia, 18: 907-960.

Graciolli, G.; Autino, A.G. \& Claps, G.L. 2007. Catalogue of American Nycteribiidae (Diptera, Hippoboscoidea). Revista Brasileira de Entomologia, 51: 142-159.

Graciolli, G.; Dick, C.W. \& Guerrero, R. 2016. Family Nycteriibidae. Zootaxa, 4122(1): 780-783.

Graciolli, G.; Zortea, M.; Carvalho, L.F.A.C. 2010. Bat flies (Diptera, Streblidae and Nycteribiidae) in a (errado area of Goiás State, Brazil. Revista Brasilera de Entomologia, 54(3): 511-514.

Guerrero, R. 1993. Catálogo de los Streblidae (Diptera: Pupipara) parásitos de murciélagos (Mammalia: Chiroptera) del nuevo mundo. I. Clave para los géneros y Nycterophiliinae. Acta Biológica Venezuélica, 14: 61-75.

Guerrero, R. 1994a. Catálogo de los Streblidae (Diptera: Pupipara) parasitos de murciélagos (Mammalia: Chiroptera) del Nuevo Mundo. II. Los grupos: pallidus, caecus, major, uniformis y longipes del género Trichobius Gervais, 1844. Acta Biológica Venezuélica, 15(1): 1-18.

Guerrero, R. 1994b. Catálogo de los Streblidae (Diptera: Pupipara) parásitos de murciélagos (Mammalia: Chiroptera) del Nuevo Mundo. IV. Trichobiinae con alas desarrolladas. Boletín de Entomología Venezolana, Nueva Serie, 9(2): 161-192.

Guerrero, R. 1995a. Catálogo de los Streblidae (Diptera: Pupipara) parásitos de murciélagos (Mammalia: Chiroptera) del Nuevo Mundo. Ill. Los gupos: dugesii, dunni y phyllostomae del género Trichobius Gervais, 1844. Acta Biológica Venezuélica, 15(3-4): 1-27.

Guerrero, R. 1995b. Catálogo de los Streblidae (Diptera: Pupipara) parásitos de murciélagos (Mammalia: Chiroptera) del Nuevo Mundo. V. Trichobiinae. Boletín de Entomología Venezolana, 10(2): 135-160. 
Guerrero, R. 1996a. Catálogo de los Streblidae (Diptera: Pupipara) parásitos de murciélagos (Mammalia: Chiroptera) del Nuevo Mundo. VI. Streblinae. Acta Biológica Venezuélica, 16(2): 1-25.

Guerrero, R. 1996b. Estudio preliminar de los ectoparásitos de los murciélagos de Pakitza, Parque Nacional Manu (Perú). In: Wilson, D.E. \& Sandoval, A. (Eds.). The Biodiversity of Southeastern Peru. Washington, Smithsonian Institution. p. 635-650.

Guerrero, R. 1997. Catálogo de los Streblidae (Diptera: Pupipara) parásitos de murciélagos (Mammalia: Chiroptera) del nuevo mundo VII. Lista de especies, hospedadores y países. Acta Biológica Venezuélica, 17: 9-24.

Guimarães, L.R. 1946. Revisão das especies sudamericanas do genero Basilia (Diptera: Nycteribiidae). Arquivos de Zoologia do Estado de São Paulo, 5(1): 1-87.

Guimarães, L.R. \& D'Andretta, M.A. 1956. Sinopse dos Nycteribiidae (Diptera do Novo Mundo). Arquivos de Zoologia do Estado de São Paulo, 10(1): $1-184$.

Instituto Geográfico Agustín Codazzi (IGAC). 1990. Fundamentos para la definición de Pisos Bioclimáticos. Bogotá, IGAC. 104p.

Lareschi, M.; Sánchez, J.P.; Autino, A.G. 2016. A review of the fleas (Insecta: Siphonaptera) from Argentina. Zootaxa, 4103: 239-258.

Linares, 0.J. 1986. Murciélagos de Venezuela. Caracas, Cuadernos Lagoven. $119 p$.

Mantilla-Meluk, H. \& Baker R.J. 2006. Systematic of small Anoura (Chiroptera: Phyllostomidae) from Colombia, with description of a new species. Occasional Papers, Museum of Texas Tech University, 261: 1-18.

Marinkelle, C. \& Grose, E.S. 1981. A list of ectoparasites of Colombian bats. Revista de Biología Tropical, 29(1): 11-20.

Marshall, A. 1981. Biology of insects ectoparasitic on bats. In: Kunz, T. (Ed.). Ecology of bats. New York, Plenum Press. p. 369-401.

Muñoz, J. 2001. Los murciélagos de Colombia; Sistemática, distribución, descripción, historia natural y ecología. Antioquia, Universidad de Antioquia. 391p.
Presley, S.J. 2004. Ectoparasitic assemblages of Paraguayan Bats: ecological and evolutionary perspectives. (PhD Dissertation). Texas Tech University, Lubbock, Texas.

Santos, C.L.C.; Dias, P.A.; Rodrigues, F.S.; Lobato, K.S.; Rosa, L.C.; Oliveira, T.G. \& Rebelo, J.M.M. 2009. Moscas Ectoparasitas (Diptera: Streblidae) de Morcegos (Mammalia: Chiroptera) do Município de São Luís, MA: Taxas de Infestação e Associações Parasito-Hospedeiro. Neotropical Entomology, 38(5): 595-601.

Solari, S.Y.; Muñoz-Saba, J.V.; Rodriguez-Mahecha, T.R.; Deffler, H.E.; Ramírez C. \& Trujillo, F. 2013. Riqueza, endemismo y conservación de los mamíferos de Colombia. Mastozoología Neotropical, 20(2): 301-365.

Tarquino-Carbonell, A.P.; Gutiérrez-Díaz, K.A.; Galindo-Espinosa, E.Y.; Reinoso-Flórez, G.; Solari, S. \& Guerrero, R. 2015. Ectoparasites associated with bats in northeastern Tolima, Colombia. Mastozoología Neotropical, 22(2): 349-358.

Timm, R.M.; Laval, R.K. \& Bernal, R.H. 1999. Claves de campo para los murciélagos de Costa Rica. Brenesia, 52: 1-32.

Wenzel, R.L. 1970. Family Streblidae. In: Papavero, N. (Ed.). A Catalogue of the Diptera of the Americas south of the United States, n. 100. São Paulo, Museu de Zoologia, Universidade de São Paulo. 25p.

Wenzel, R.L. 1976. The streblid batflies of Venezuela (Diptera: Streblidae). Brigham Young University Science Bulletin, Biological Series, 20(4): 1-177.

Wenzel, R.L.; Tipton, V.J. \& Kiewlicz, A. 1966. The streblid batflies of Panama (Diptera: Calypterae: Streblidae). In: Wenzel, R.L. \& Tipton, V.J. (Eds.). Ectoparasites of Panama. Chicago, Field Museum of Natural History. p. 405-675.

Wisnivesky, C. 2003. Ecología y epidemiología de las infecciones parasitarias. Costa Rica, Libro Universitario Regional. 398p.

Zurc, D. \& Velazco, P.M. 2010. Análisis morfológico y morfométrico de Carollia colombiana Cuartas et al., 2001 y C. monohernadezi Muñoz et al., 2004 (Phyllostomidae: Carollinae) en Colombia. Chiroptera Neotropical, 16: 549-567. 